\title{
R-HPDC in South Africa
}

\section{CURLE Ulyate A. ${ }^{a}$, MÖLLER Heinrich ${ }^{\mathrm{b}}$ and GOVENDER Gonasagren ${ }^{\mathrm{c}}$}

\author{
Council for Scientific and Industrial Research, Materials Science and Manufacturing, Pretoria, \\ South Africa \\ a ucurle@csir.co.za, ${ }^{b}$ hmoller@csir.co.za, ${ }^{\mathrm{c}}$ sgovender@csir.co.za
}

Keywords: CSIR-RCS; SSM; APT; T6; Industrial scale

\begin{abstract}
The history of semi-solid metal forming and in particular rheo-high pressure die casting at the Council for Scientific and Industrial Research in South Africa is discussed. Processing flexibility is demonstrated on the Al-Si-Mg, Al-Mg-Si, Al-Cu-Mg and Al-Zn-Mg-Cu casting and wrought alloy systems as well as on high purity aluminium, unmodified Al-Si binary eutectic, metal matrix composites and magnesium alloys. Material properties are highlighted.
\end{abstract}

\section{Introduction}

The Council for Scientific and Industrial Research (CSIR) in South Africa has a long history of semi-solid processing and the aim of this paper is to highlight developments and achievements of the CSIR R-HPDC Technology.

\section{CSIR SSM history}

The CSIR has been actively involved in research and development (R\&D) in the field of semisolid metal (SSM) forming for the past 12 years. In the period 2000 to 2003 a project was launched at the CSIR in the area of SSM forming which was funded by the Innovation Fund. During this period the CSIR, with its research partners, developed a process to prepare liquid metal to the semisolid state [1] for forming via high pressure die casting (HPDC) or other techniques which was provisionally patented in 2004 and finally filed in 2008 [2]. This project was predominantly funded by the CSIR from 2003 to 2005 . The project was further funded by the CSIR together with the Department of Science and Technology (DST) through the Light Metals Development Network (LMDN) under the Advanced Metals Initiative (AMI) from 2006 to date.

\section{CSIR Rheocasting System}

The CSIR focused on commercialising this process together with fundamental research on SSM forming since 2003. The development of a commercial prototype of the patented process, now referred to as the CSIR Rheocasting System (CSIR-RCS) Device was manufactured and commissioned in 2004. In 2005 and 2006 demonstration of the process in an industrial environment was attempted by using a local industry partner. An industrial scale HPDC research facility was established at the CSIR in 2008-2009 using infrastructure funding sourced from the LMDN project, due to the difficulty in accessing commercial HPDC facilities for assessing the technology. Research and development at the CSIR has made significant progress since establishing this laboratory. The research team has focussed on optimising the CSIR-RCS for process stability and energy consumption. Opportunities and challenges of applications of this system for the aerospace and automotive market have been discussed [3-5]. 


\section{R-HPDC Cell}

The technology of pairing the CSIR-RCS device with a high pressure die casting (HPDC) machine is termed rheo-high pressure die casting (R-HPDC) and in South Africa is called the CSIR R-HPDC Technology. Currently there are two versions of the CSIR R-HPDC Technology distinguished by its scale of operation. Figure 1 shows the two different cell scales with all the cell elements while Table 1 gives a basic overview of the specifications for the cell elements.
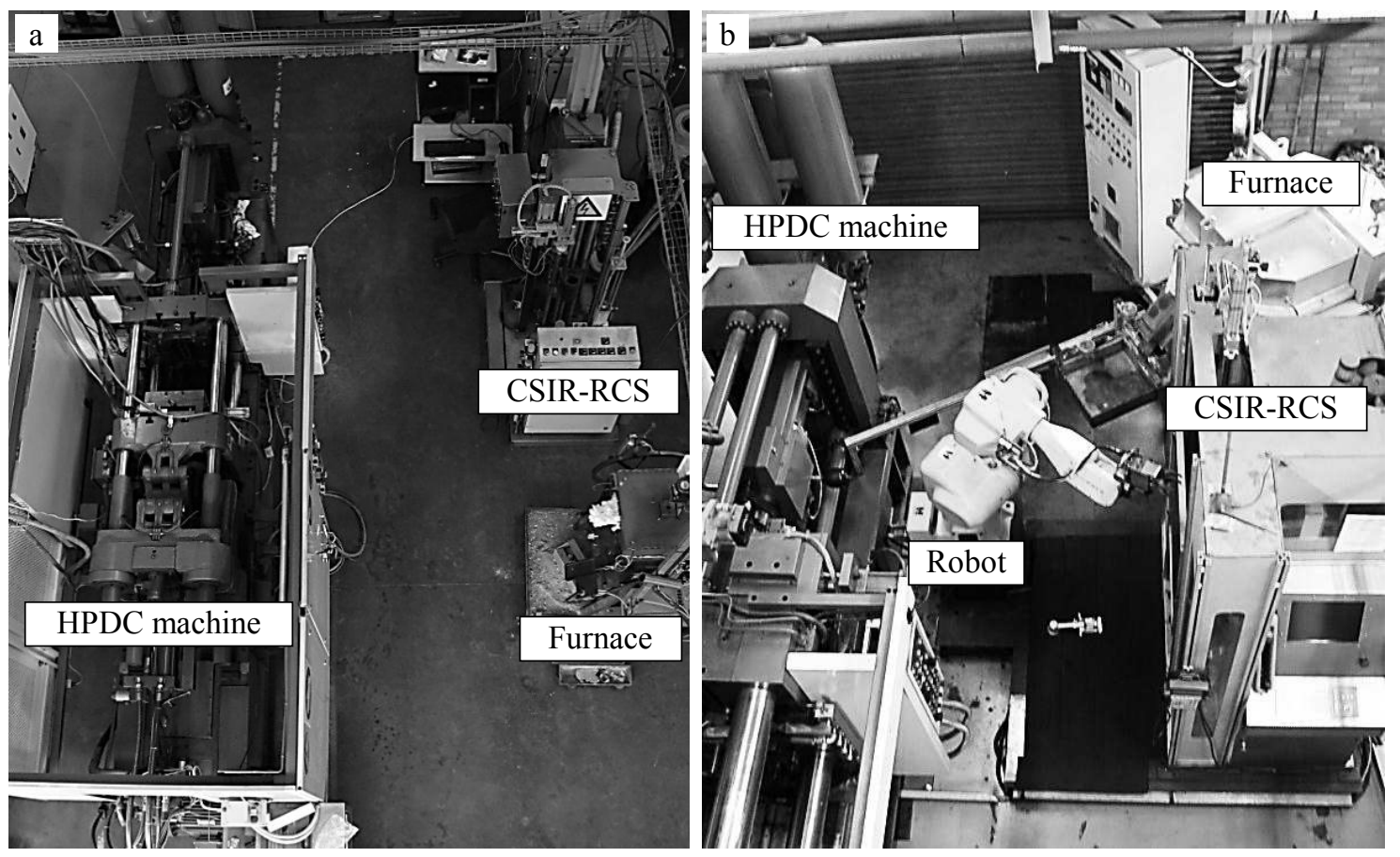

Figure 1. CSIR R-HPDC Cell arrangements (a) small scale and (b) large scale.

Table 1. Basic specifications for cell elements of the small and large scale CSIR R-HPDC Cells.

\begin{tabular}{rccc} 
Cell element / Function & & Small scale cell & Large scale cell \\
\hline CSIR RCS Device & Model & $\underline{1 c e}$ & $\underline{1 C e}$ \\
\hline Furnace & Make & Custom & Westofen \\
& Type & Ladle & Controlled dosing \\
& Capacity & $25 \mathrm{~kg}$ & $240 \mathrm{~kg}$ \\
\hline HPDC machine & Make & LK & LK \\
& Model & DCC130 & DCC630 \\
& Type & Shot control & Shot control \\
\hline Material transfer & Type & Operator & Robotic \\
& Make & - & Fanuc \\
\hline Element integration & Type & None & Computer control \\
\hline Operation & Type & Manual & Automatic / Manual \\
\hline
\end{tabular}

The main difference, besides scale, is the mode of material transfer between the cell elements. The small cell is manual operator based while the large cell is automatic robot based. The basic sequence of operations in the cell is the following. Liquid alloy metal is ladled or dosed from the furnace into the processing cup. The processing cup is transferred by the operator or robot to the rheocasting system for processing. The processing cup is ejected from the rheocasting system and 
transferred, again, by the operator or robot to the HPDC machine. The injection piston is triggered to follow the programmed shot profile once the semi-solid metal billet is emptied into the shot sleeve of the HPDC machine.

\section{Alloy processing}

The CSIR-RCS demonstrates its flexibility by the ability to process a number of different types of material including aluminium casting alloys [6,7], aluminium wrought alloys [8,9], high purity aluminium [10], unmodified aluminium-silicon binary eutectic [11], metal matrix composites [12] and magnesium casting alloys $[13,14]$.

The typical procedure to prepare for processing an alloy is by choosing the alloy composition and custom preparing the alloy if the commercial alloy is not available. The melt is prepared in the furnace and a sample is poured for chemical analysis with an optical emission spectrometer (OES) on site. Melt parameters have also been investigated [15]. The actual composition from the OES is then used as input to a thermodynamic database to calculate the theoretical thermal properties of the liquid alloy including the liquidus temperature and the 0.3 solid fraction temperature $\left(f_{s}^{0.3}\right)$. The pouring temperature with a superheat of between 10 and $20{ }^{\circ} \mathrm{C}$ is calculated and the furnace temperature is set to stabilise and control at the calculated pouring temperature. Processing is ready to commence at this point.

The processing sequence starts by ladling the liquid alloy into the processing cup and transferring to the CSIR-RCS. The cup is positioned in the processing coils where the cooling rate is controlled by the forced air cooling while the stirring action is controlled by the power input into the induction coil [2]. Processing continues until the $f_{s}^{0.3}$ temperature is reached at which point the processing cup is ejected from the processing coil. The SSM material in the cup is then transferred to the HPDC machine and emptied into the shot sleeve and subsequently HPDC.

Resultant as-cast microstructures of alloy systems cast using the CSIR R-HPDC Technology is presented in Figure 2 through Figure 9. Each figure will be discussed in short. Microstructures of alloy systems only are shown in this section because of the similarity in structure within a system regardless of the specific alloy.

Al-Si-Mg alloys. Figure 2 is typical light optical microscope (LOM) image of a hypoeutectic Al-Si$\mathrm{Mg}$ alloy (A356 and F357). The primary-(Al) grains (light grey) are globular with a high spherical shape factor. Grains with a lower spherical shape factor and larger aspect ratio are also visible and their shape mainly depends on their actual position in the magnetic field during stirring. The other feature of this type of alloy is the fraction of eutectic visible (dark grey). The structure of the $\mathrm{Si}$ in the eutectic is very fine indicating modification. Modification could either be the result of chemical addition to the alloy like $\mathrm{Sr}$ or $\mathrm{Na}$ for instance. But modification is also a result of a high cooling rate as the case with HPDC.

Al-Mg-Si alloys. Figure 3 is a LOM image of the microstructure of an Al-Mg-Si alloy i.e. AA6082. This microstructure is characterised by a very large fraction of primary-(Al) grains. The grains are globular and relatively large and more rosettes are also visible indicating a small number of nuclei at the start of solidification and a long period of grain growth during rheo-processing. Fe based intermetallics as well as $\mathrm{Mg}_{2} \mathrm{Si}$ are found in the inter-globular regions. $\mathrm{Mg}$ and $\mathrm{Si}$ is the base for precipitate strengthening during heat treatment while the Fe intermetallics are detrimental to ductility of the alloy.

Al-Cu-Mg alloys. Figure 4 shows a scanning electron microscope (SEM) back scattered image (BSI) of an Al-Cu-Mg alloy i.e. 2139. Again the microstructure is primarily equi-axed primary-(Al) globular grain and the light phase is the eutectic of $\mathrm{Cu}$ and $\mathrm{Mg}$ alloying elements and minor alloying elements if added. 
Al-Zn-Mg-Cu alloys. Figure 5 this time shows a SEM BSI of an Al-Zn-Mg-Cu alloy i.e. 7076. The microstructure is dominated by equi-axed primary-(Al) globular grains and the light phase in this case is the eutectic of $\mathrm{Zn}, \mathrm{Mg}$ and $\mathrm{Cu}$ alloying elements also with minor alloying elements if added. It is indeed difficult to distinguish between the microstructures of Figure 4 and 5 .

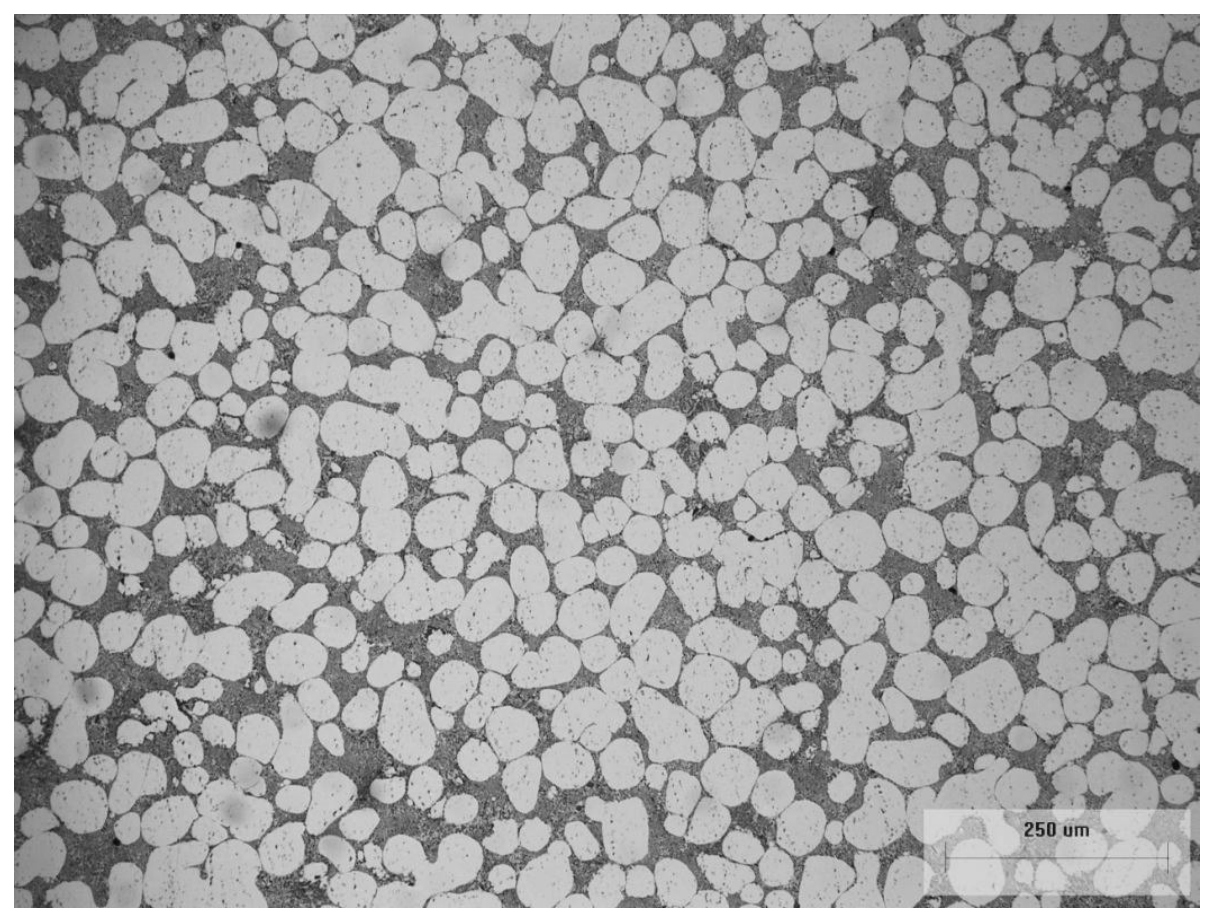

Figure 2. As-cast microstructure of a CSIR R-HPDC Al-Si-Mg alloy.

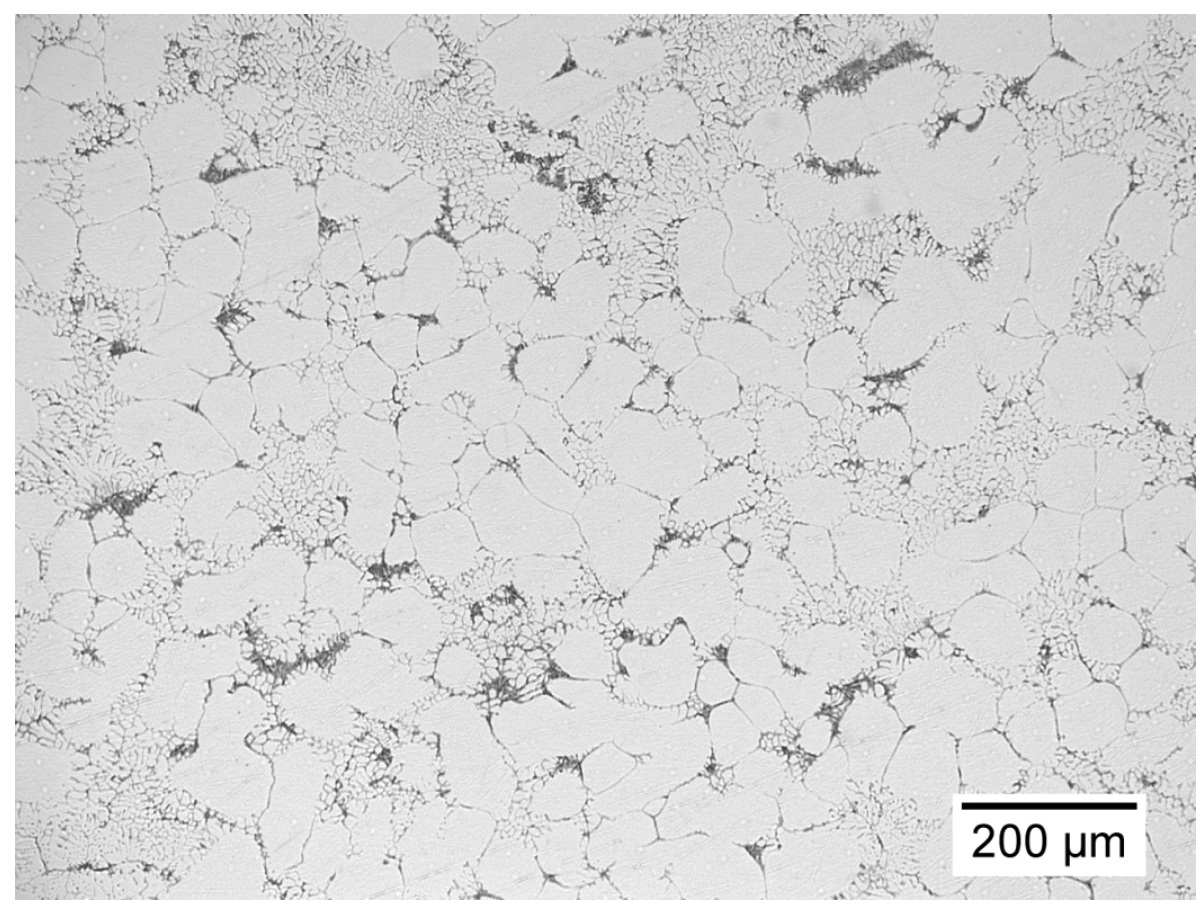

Figure 3. As-cast microstructure of a CSIR R-HPDC Al-Mg-Si alloy. [8] 


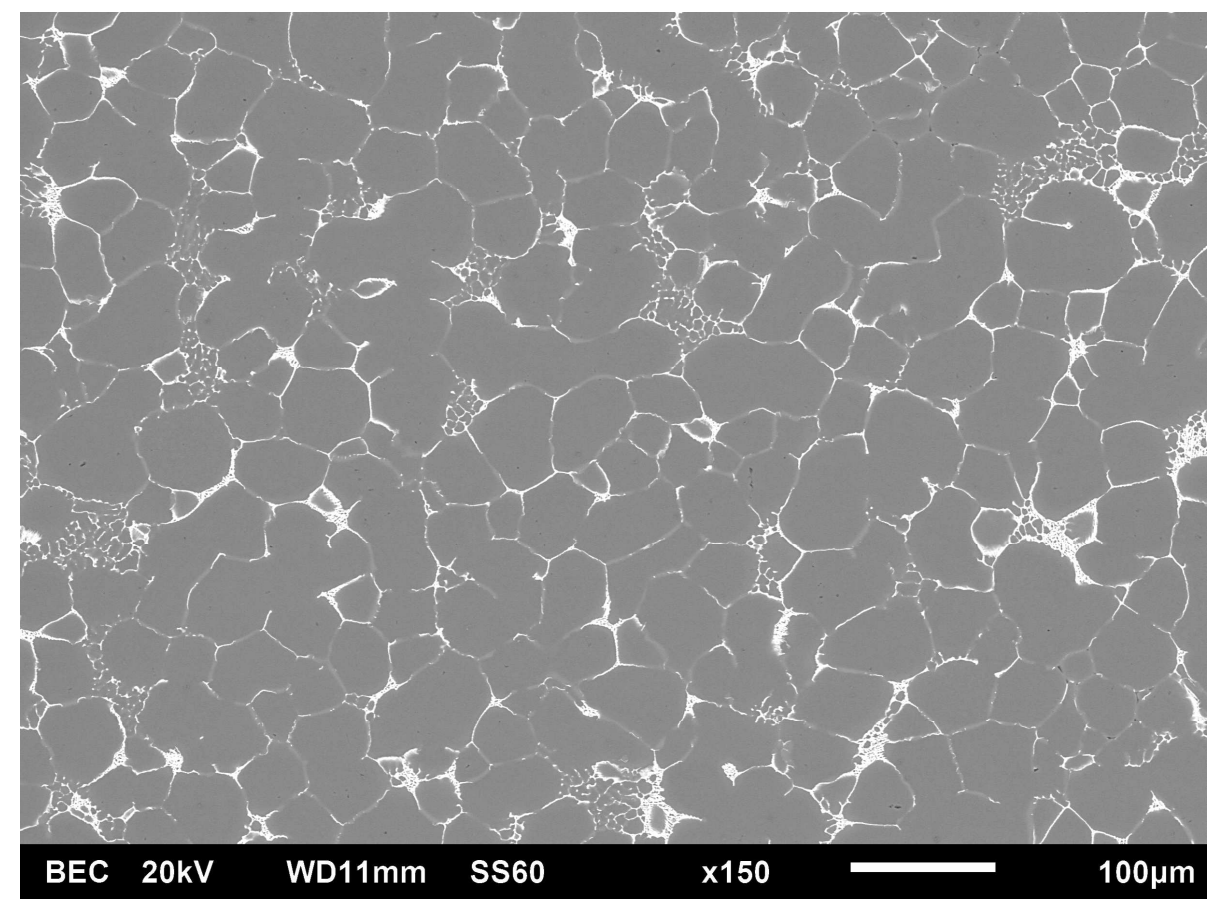

Figure 4. As-cast microstructure of a CSIR R-HPDC Al-Cu-Mg alloy.

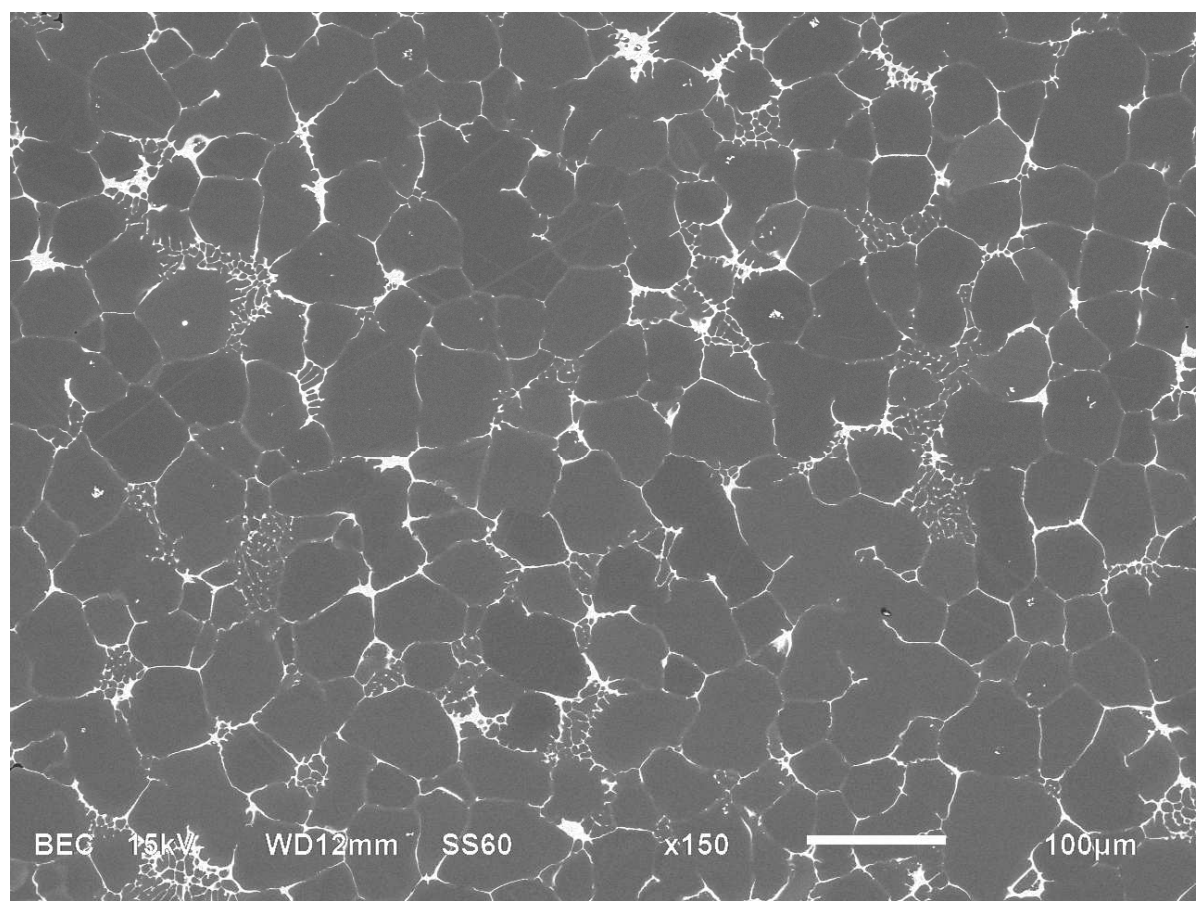

Figure 5. As-cast microstructure of a CSIR R-HPDC Al-Zn-Mg-Cu alloy.

High purity aluminium. Figure 6 shows the microstructure of CSIR R-HPDC high purity Al which is unique. Solidification of pure metals is an invariant reaction which does not exhibit a solidification temperature interval like alloys. It is possible to semi-solid cast pure metals on account of the solidification time interval which is related to the latent heat of fusion of the metal and the cooling conditions [10]. The grain structure is evaluated in detail during this conference [16].

Unmodified Al-Si binary eutectic. Figure 7 shows a LOM image of an unmodified Al-Si binary eutectic. The invariant reaction argument and the principle of a solidification time range is the same in this case as for high purity $\mathrm{Al}$ above. The structure is unintuitive on account that the two phase grains are not modified as in the case of a slow cooling rate while the inter-grain regions has a 
modified structure characteristic of a high cooling rate. Note that it does not make sense to refer to either the coarse or fine structure as the eutectic because the whole alloy has the binary eutectic composition. [11]



Figure 6. As-cast microstructure of a CSIR R-HPDC high purity Al. [10]

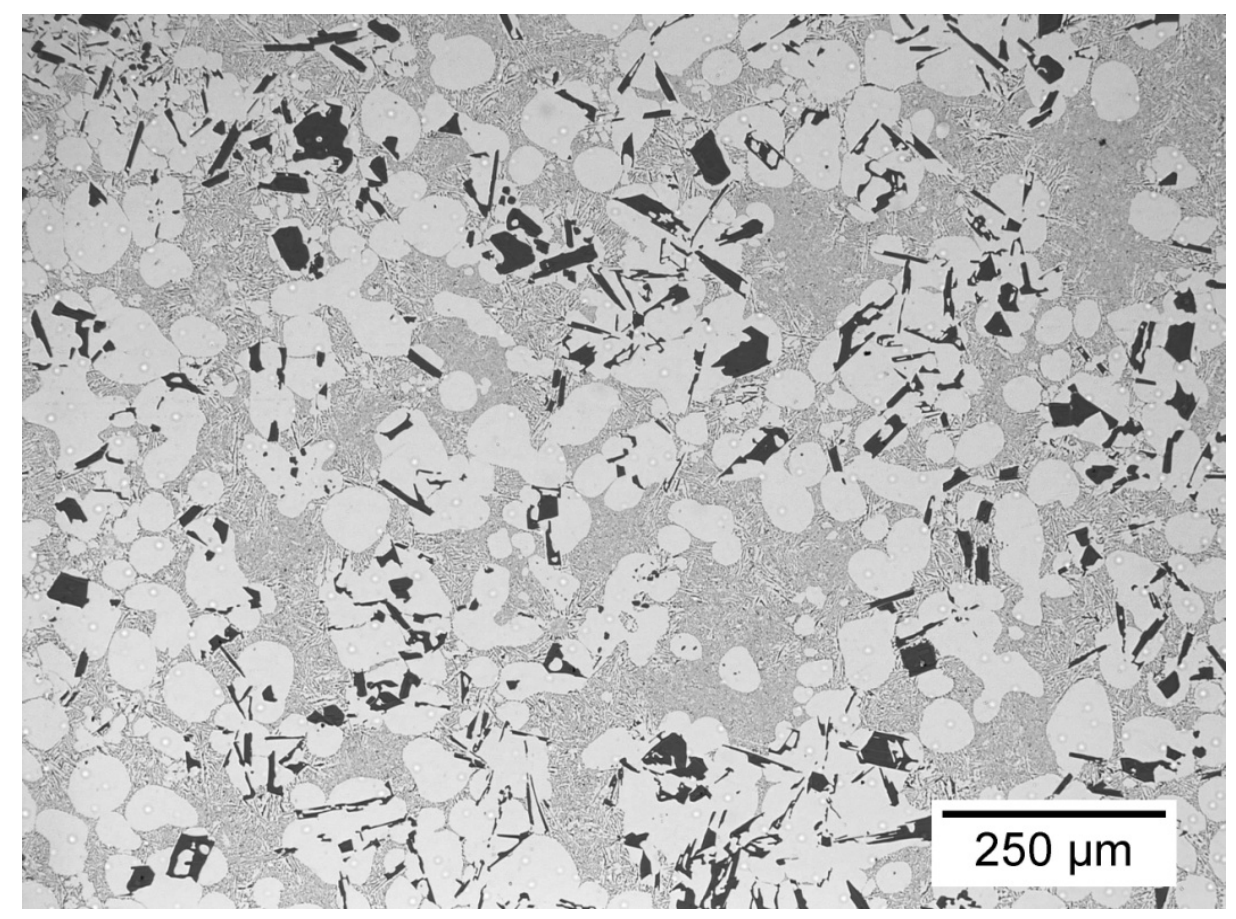

Figure 7. As-cast microstructure of a CSIR R-HPDC unmodified Al-Si binary eutectic. [11]

Metal matrix composites. Figure 8 shows a LOM image of a CSIR R-HPDC SiCp/A359 metal matrix composite (MMC). A359 is a hypoeutectic Al-Si alloy and has the same features as Figure 2 except that there are $\mathrm{SiC}$ particles dispersed throughout the eutectic in the inter-globular regions while the primary-(Al) grains are still equi-axed.

Mg-Al alloys. Figure 9 shows a LOM image of a hypoeutectic $\mathrm{Mg}$-Al alloy and again as in all the cases above is characterised by a globular primary-(Mg) with an inter-globular eutectic phase indicative of non-equilibrium solidification and is presented at this conference [14]. 


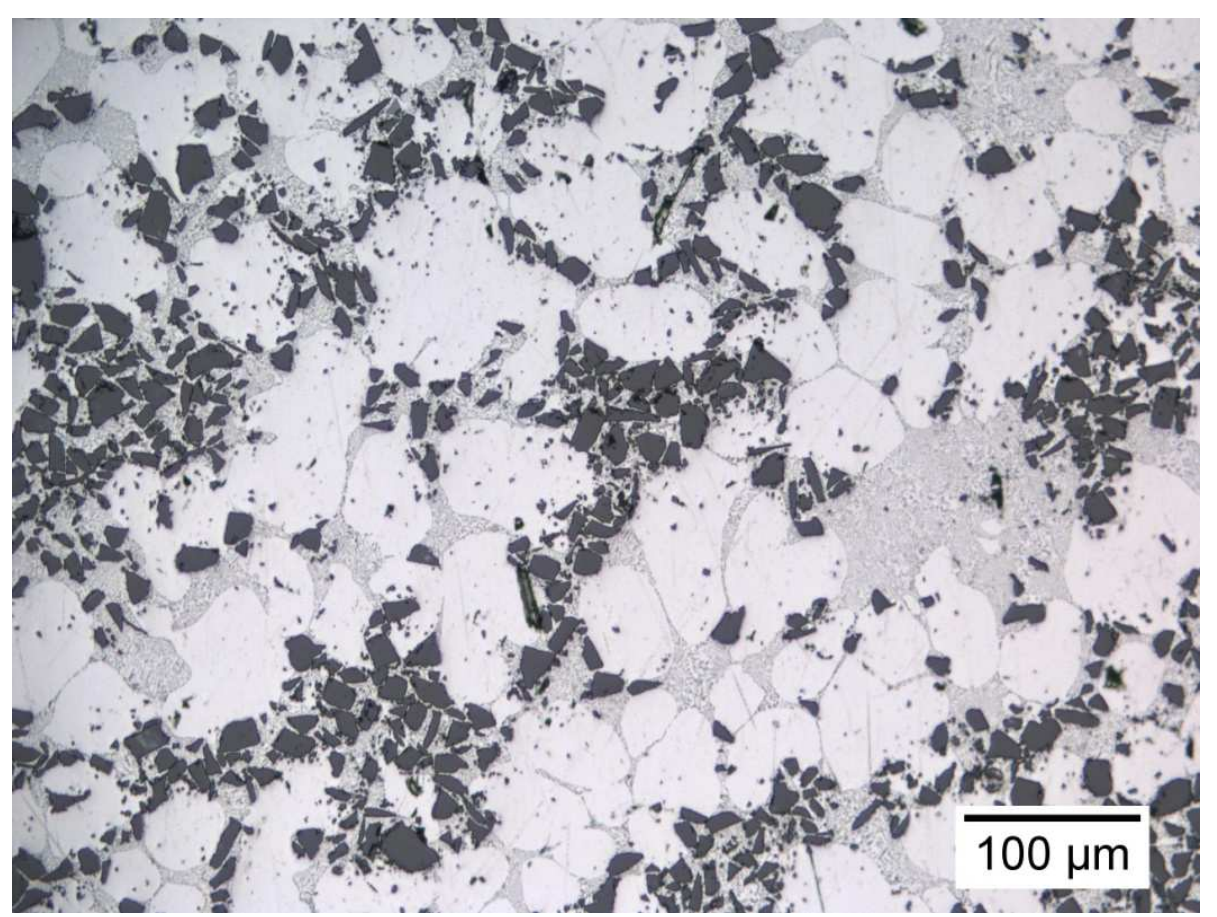

Figure 8. As-cast microstructure of a CSIR R-HPDC SiCp/A359 MMC. [12]

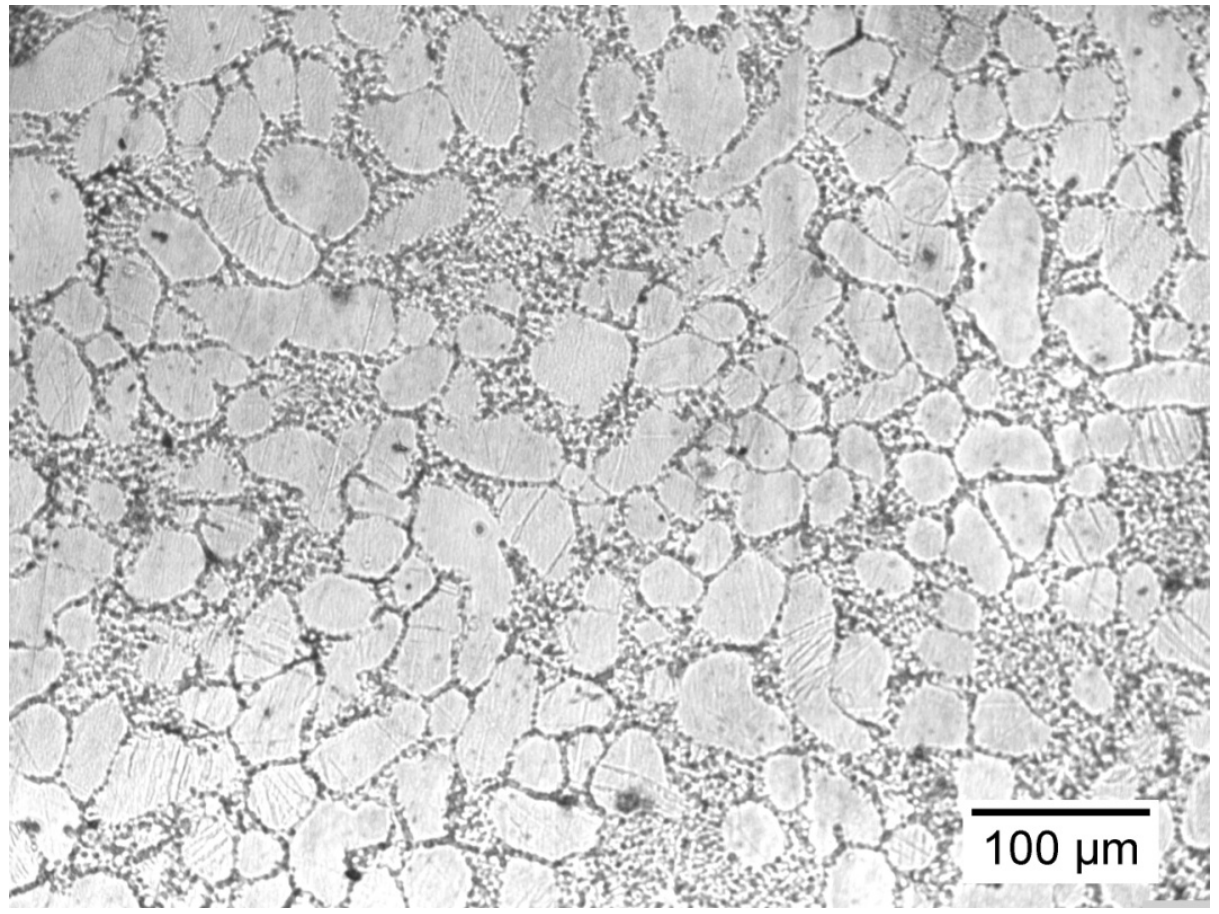

Figure 9. As-cast microstructure of a CSIR R-HPDC Mg-Al alloy.

Surface Liquid Segregation. Surface liquid segregation is characteristic of all SSM processes, especially rheocasting processes, in all components and has been characterised in Al-Si-Mg [17], $\mathrm{Al}-\mathrm{Cu}-\mathrm{Mg}$ and $\mathrm{Al}-\mathrm{Zn}-\mathrm{Mg}-\mathrm{Cu}[18]$ alloys. 


\section{Component production}

The CSIR has four die sets to produce components on the different R-HPDC Cell scales. Figure 10 shows that plate and taper rod components used on the small scale for basic research i.e. microstructure characterisation, homogenisation and solution heat treatments, optimisation of artificial ageing heat treatments, measuring tensile properties, corrosion and welding.
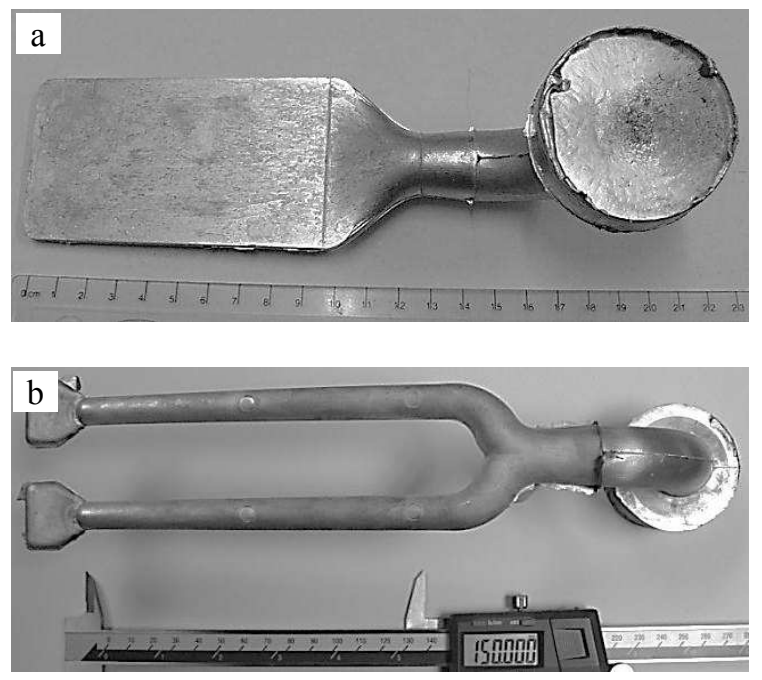

Figure 10. Small scale research components (a) Plate [10] and (b) Taper rods.

Figure 11 shows the two industrial components, an automotive brake calliper and an engine mounting bracket, for the large scale R-HPDC Cell to characterise and evaluate the CSIR R-HPDC Technology on an industrial scale. The brake calliper in an Al-Si-Mg alloy [19] and the engine mounting bracket in an $\mathrm{Al}-\mathrm{Zn}-\mathrm{Mg}-\mathrm{Cu}$ alloy [20] were evaluated. Laboratory scale heat treatment for tensile property evaluation was reported before [21] while the industrial scale heat treatment is reported in this conference [22].
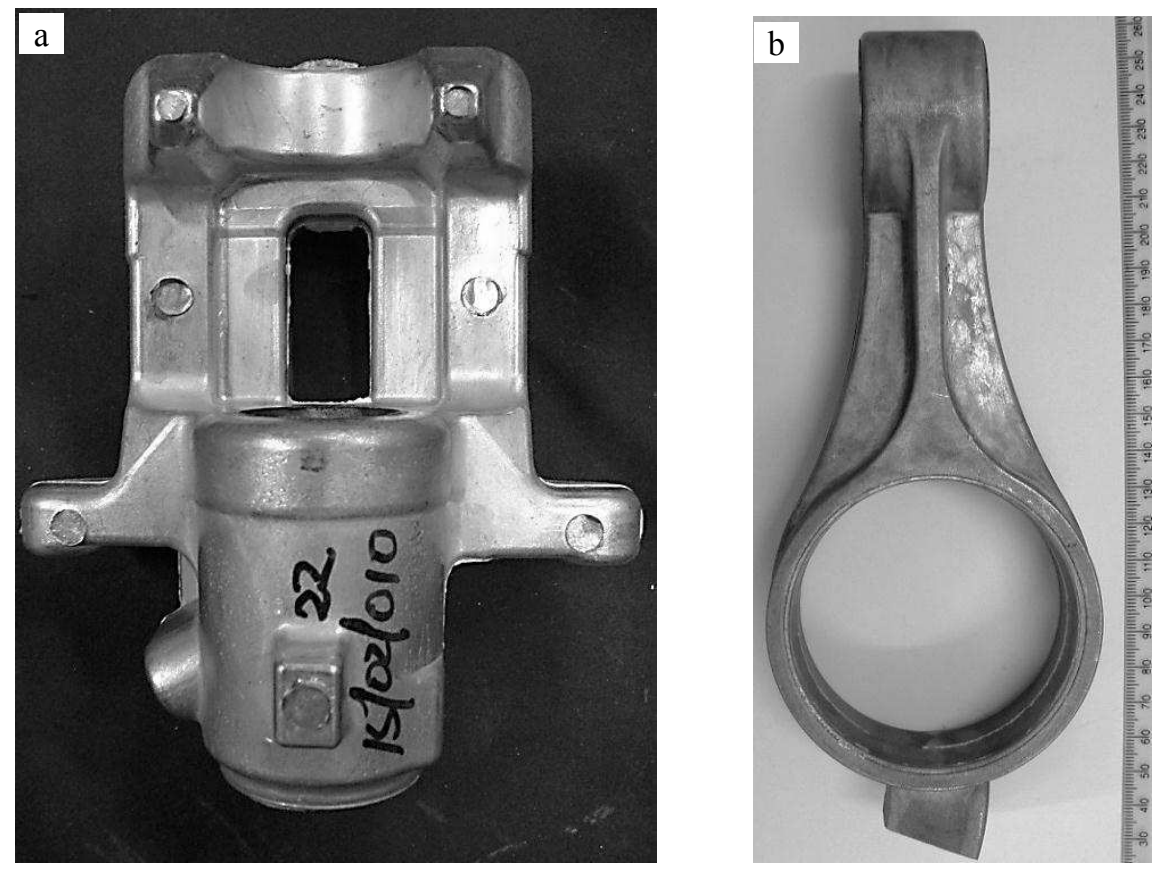

Figure 10. Large scale industrial research components (a) Brake calliper [19] and (b) Engine mounting bracket [20]. 


\section{Material properties}

Tensile properties. The first aim of heat treating SSM processed heat treatable alloys is to achieve, at least, the minimum tensile properties specification. The next step is to work towards the typical properties of the specific alloy in the same heat treated condition. Table 2 is a collation of some of the tensile properties achieved for specific alloy system designations; indicated here for self comparison.

Table 2. Collated table of CSIR R-HPDC T6 and some T4 tensile properties for heat treatable aluminium alloys by alloy system. A number of magnesium alloys are included.

\begin{tabular}{|c|c|c|c|c|}
\hline Alloy system & YS [MPa] & UTS [MPa] & Elongation [\%] & Reference \\
\hline \multicolumn{5}{|l|}{ Al-Si-Mg } \\
\hline $\mathrm{F} 357^{\#}$ & 176 & 299 & 18.0 & [34] \\
\hline F357 & 304 & 365 & 10.6 & [34] \\
\hline \multicolumn{5}{|l|}{$A l-M g-S i$} \\
\hline 6004 & 207 & 237 & 12.0 & {$[32]$} \\
\hline $6082^{*}$ & 323 & 344 & 4.2 & {$[32]$} \\
\hline $6082^{*}$ & 351 & 385 & 5.1 & {$[8]$} \\
\hline \multicolumn{5}{|l|}{$\mathrm{Al}-\mathrm{Cu}-\mathrm{Mg}$} \\
\hline 206 & 330 & 379 & 8.0 & [7] \\
\hline $2024^{*}$ & 351 & 385 & 5.1 & {$[8]$} \\
\hline \multicolumn{5}{|l|}{$A l-C u-M g-A g$} \\
\hline 2139 & 361 & 439 & 10.7 & [37] \\
\hline 2139 & 423 & 475 & 6.5 & {$[37]$} \\
\hline \multicolumn{5}{|l|}{$A l-Z n-M g$} \\
\hline 7017 & 361 & 409 & 7.1 & {$[38]$} \\
\hline \multicolumn{5}{|l|}{$\mathrm{Al}-\mathrm{Zn}-\mathrm{Mg}-\mathrm{Cu}$} \\
\hline 7076 & 466 & 515 & 9.0 & unp. \\
\hline $7075^{*}$ & 467 & 513 & 3.5 & {$[8]$} \\
\hline 7150 & 516 & 537 & 2.0 & unp. \\
\hline \multicolumn{5}{|l|}{$M g-A l-M n$} \\
\hline $\mathrm{AM} 5 \mathrm{~A}^{* \#}$ & 88 & 231 & 16.7 & {$[14]$} \\
\hline $\mathrm{AM} 6 \mathrm{~B}^{* \#}$ & 89 & 226 & 12.1 & {$[14]$} \\
\hline \multicolumn{5}{|l|}{$M g-A l-Z n$} \\
\hline AZ91D ${ }^{* \#}$ & 104 & 267 & 12.3 & [14] \\
\hline
\end{tabular}

The largest part of fundamental research at the CSIR was focused on the Al-Si-Mg alloy system, investigating topics including various heat treatment conditions [23-26], heat treatment time and temperature response [27,28], the effect of elevated impurity levels [29], comparing dendritic and globular microstructures [30]. The Al-Si-Mg casting alloy system was compared to the Al-Mg-Si wrought alloy system for which the strengthening mechanism is similar [31,32]. The factors 
influencing tensile properties for the Al-Si-Mg system was also delineated [33]. Ultimately, atom probe tomography (APT) was used to uncover the mechanism for precipitation strengthening in this system [34].

The effects of minor alloying elements were investigated [7,35] as well as a solution heat treatment optimisation for the Al-Cu-Mg alloy system [36]. Heat treatment of a Al-Cu-Mg-Ag alloy is the topic of presentation in this conference [37].

Heat treatment of an $\mathrm{Al}-\mathrm{Zn}-\mathrm{Mg}$ alloy is presented at this conference [38] while solution heat treatment of an Al-Zn-Mg-Cu alloy was studied before [39].

Corrosion. It is expected that the effect of the surface liquid segregation layer will have an impact on corrosion properties of castings. Pitting was investigated for an Al-Si-Mg alloy [40] while corrosion was investigated for $\mathrm{Cu}$-containing wrought alloy systems [41].

A corrosion comparison of HPDC and R-HPDC magnesium alloys is presented at this conference [42].

Welding. Laser welding of Al-Si-Mg was investigated on a number of occasions [43-45] as well as the effect of a number of heat treatments on the welds [46-48]. Property and quality optimization of a laser welded Al-Si-Mg alloy will be presented at this conference [49].

Fusion welding of an Al-Zn-Mg alloy will also be presented at this conference [50].

\section{Approach}

The intent of R\&D at the CSIR is to provide customers with a total turn-key solution including alloy selection, alloy processing, die design, HPDC optimisation and heat treatment optimisation to produce components with final requisite material properties. These properties are not limited to tensile properties but include fatigue, impact, stress corrosion cracking, anodising, welding and wear. The aim is at reducing the risk of failure due to past mistakes by not considering the entire end to end value chain.

\section{Future}

One of the aims is to produce a material properties database for design purposes including tensile, fatigue, impact, corrosion, welding, anodising and stress corrosion cracking properties, especially for the high strength heat treatable aluminium alloy systems. There is a market for SSM technology and the designed components must be chosen such that they make both technical and economic sense and the aim is to create awareness for the fit-for-purpose design.

\section{Acknowledgements}

The authors would like to extent their gratitude towards the following stakeholders:

Funding: the Innovation Fund (now under the Technology Innovation Agency) and Department of Science and Technology;

Continued support: Dr L. Botha as Executive Director at the Materials Science and Manufacturing (MSM) operating unit, Dr. O.F.R.A. Damm as Contracts Manager at MSM, Dr. W. Du Preez as the Competency Area Manager at the Light Metals (LM) group, D. Hope and N. Bapst as Project Managers at LM and C. Stearn and M. Mojalefa for Administration duties; and

Technical support: J.D. Wilkins, M. Grobler and D. Ntuli for casting, P. Rossouw for alloying, C McDuling and E. Guldenpfennig for mechanical testing and A. Grobler for sample preparation (all at LM). 


\section{References}

[1] L. Ivanchev, D. Wilkins, G. Govender, Method and apparatus for rheo-processing of semisolid metal alloys, Proceedings of the 8th International Conference on Semi-Solid Processing of Alloys and Composites (2004) 595-601.

[2] R. Bruwer, J.D. Wilkins, L.H. Ivanchev, P. Rossouw, O.F.R.A. Damm, U.S. Patent 7,368,690 (2008).

[3] H.N. Chou, G. Govender, L. Ivanchev, Opportunities and challenges for use of SSM forming in the aerospace industry, Solid State Phenomena 116-117 (2006) 92-95.

[4] G. Govender, L. Ivanchev, N. Jahajeeah, R. Bëan, Application of CSIR rheocasting technology for the production of an automotive component, Solid State Phenomena 116-117 (2006) 501-504.

[5] L. Ivanchev, D. Wilkins, G. Govender, W. Du Preez, R. Bean, Rheo-processing of semi-solid metal alloys: A new technology for manufacturing automotive and aerospace components, South African Journal of Science 104 (2008) 257-259.

[6] H. Möller, G. Govender, W.E. Stumpf, P.C Pistorius, Comparison of the heat treatment response of semi-solid metal processed alloys A356 and F357, International Journal of Cast Metals Research 23 (2010) 37-43.

[7] E.P. Masuku, L. Ivanchev, G. Govender, H. Möller, Rheocasting of Al-Cu alloy A201 with different silver contents, Solid State Phenomena 141-143 (2008) 151-156.

[8] U.A. Curle, Semi-solid near-net shape rheocasting of heat treatable wrought aluminum alloys, Transactions of Nonferrous Metals Society of China 20 (2010) 1719-1724.

[9] U.A. Curle, G. Govender, Semi-solid rheocasting of grain refined aluminum alloy 7075, Transactions of Nonferrous Metals Society of China 20 (2010) s832-s836.

[10] U.A. Curle, H. Möller, J.D. Wilkins, Shape rheocasting of high purity aluminium, Scripta Materialia 64 (2011) 479-482.

[11] U.A. Curle, H. Möller, J.D. Wilkins, Shape rheocasting of unmodified Al-Si binary eutectic, Materials Letters, 65 (2011) 1469-1472.

[12] U.A. Curle, L. Ivanchev, Wear of semi-solid rheocast SiCp/Al metal matrix composites, Transactions of Nonferrous Metals Society of China 20 (2010) s852-s856.

[13] L. Ivanchev, G. Govender, SSM HPDC of magnesium alloys AZ91D and AM60B, Proceedings of the 8th International Conference on Semi-Solid Processing of Alloys and Composites (2004) 579-585.

[14] U.A. Curle, J.D. Wilkins, G. Govender, R-HPDC of magnesium alloys. Solid State Phenomena (2012) Accepted for publication.

[15] L.G. Juganan, G. Govender, A.F. Mulaba-Bafubiandi, Metallurgical and foundry parameters for the SSM forming of high strength aluminium-zinc-magnesium-copper (7075) alloy, Materials Science Forum 618-619 (2009) 611-614.

[16] S. George, R.D. Knutsen, Evolution of the solidification microstructure of rheocast high purity aluminium, Solid State Phenomena (2012) Accepted for publication.

[17] G. Govender, H. Möller, Evaluation of surface chemical segregation of semi-solid cast aluminium alloy A356, Solid State Phenomena 141-143 (2008) 433-438.

[18] H. Möller, U.A. Curle, E.P. Masuku, Characterization of surface liquid segregation in SSMHPDC aluminium alloys 7075, 2024, 6082 and A201, Transactions of Nonferrous Metals Society of China 20 (2010) s847-s851.

[19] U.A. Curle, J.D. Wilkins, G. Govender, Industrial semi-solid rheocasting of aluminum A356 brake calipers. Advances in Materials Science and Engineering (2011) no. 195406.

[20] U.A. Curle, Rheocasting an engine mounting bracket in commercial 7075, Materials Science Forum 690 (2011) 133-136.

[21] H. Möller, G. Govender, W.E. Stumpf, Application of shortened heat treatment cycles on A356 automotive brake calipers with respective globular and dendritic microstructures, Transactions of Nonferrous Metals Society of China 20 (2010) 1780-1785. 
[22] L. Chauke, H. Möller, U.A. Curle, G. Govender, Industrial heat treatment of R-HPDC A356 automotive brake callipers, Solid State Phenomena (2012) Accepted for publication.

[23] H. Möller, G. Govender, W.E. Stumpf, The natural and artificial aging response of the semisolid metal processed Al-Si-Mg alloy A356, International Journal of Cast Metals Research 20 (2007) 340-346

[24] H. Möller, G. Govender, W.E. Stumpf, The T6 heat treatment of semi-solid metal processed alloy A356, Open Materials Science Journal 2 (2008) 6-10.

[25] H. Möller, G. Govender, W.E. Stumpf, R.D. Knutsen, Influence of temper condition on the microstructure and mechanical properties of semi-solid metal processed Al-Si-Mg alloy A356. International Journal of Cast Metals Research 22 (2009) 417-421.

[26] H. Möller, G. Govender, W.E. Stumpf, The T5 heat treatment of semi-solid metal processed alloy F357, Materials Science Forum 618-619 (2009) 365-368.

[27] H. Möller, G. Govender, W.E. Stumpf, Investigation of the T4 andT6 heat treatment cycles of semi-solid metal processed alloy A356, Open Materials Science Journal 2 (2008) 11-18.

[28] H. Möller, G. Govender, W.E. Stumpf, The natural and artificial aging response of semi-solid metal processed alloy A356, Solid State Phenomena 141-143 (2008) 737-742.

[29] H. Möller, G. Govender, W.E. Stumpf. Influence of elevated Fe, Ni and Cr levels on tensile properties of SSM-HPDC Al-Si-Mg alloy F357, Transactions of Nonferrous Metals Society of China 20 (2010) s842-s846.

[30] H. Möller, G. Govender, P. Rossouw, W.E. Stumpf, The influence of prior natural aging on the subsequent artificial aging response of aluminium alloy A356 with respective globular and dendritic microstructures, Advances in Materials Science and Engineering (2011) no. 375150.

[31] H. Möller, G. Govender, W.E. Stumpf, Comparison of the heat treatment response of wrought and SSM-HPDC alloy 6082, Materials Science Forum 690 (2011) 242-245.

[32] H. Möller, G. Govender, W.E. Stumpf, Comparison of the heat treatment response of SSMHPDC 6082 and 6004 wrought alloys with A356 and F357 casting alloys, Materials Science Forum 690 (2011) 53-56.

[33] H. Möller, G. Govender, W.E. Stumpf, Factors influencing tensile mechanical properties of Al-7Si-Mg casting alloys A356/7. TMS Light Metals (2012) 467-471.

[34] G. Sha, H. Möller, W.E. Stumpf, J.H. Xia, G. Govender, S.P. Ringer, Solute-nanostructures and their strengthening effects in Al-7Si-0.6Mg alloy F357, Acta Materialia 60 (2012) 692701.

[35] H. Möller, E.P. Masuku, U.A. Curle, P.C. Pistorius, R.D. Knutsen, G. Govender, The influence of $\mathrm{Mn}$ on the tensile properties of SSM-HPDC Al-Cu-Mg-Ag alloy A201, Journal of the South African Institute of Mining and Metallurgy 111 (2011) 167-171.

[36] E.P. Masuku, L. Ivanchev, G. Govender, H. Möller, R.D. Knutsen, Optimisation of the solution heat treatment of rheoprocessed alloys A206 and A201, Materials Science Forum 618-619 (2009) 353-356.

[37] H. Möller, G. Govender, The heat treatment of rheo-high pressure die cast Al-Cu-Mg-Ag alloy 2139, Solid State Phenomena (2012) Accepted for publication.

[38] H. Möller, G. Govender, The heat treatment of rheo-high pressure die cast Al-Zn-Mg alloy 7017, Solid State Phenomena (2012) Accepted for publication.

[39] N.E. Mazibuko, U.A. Curle, Effect of solution heat treatment time on a rheocast Al-Zn-MgCu alloy, Materials Science Forum 690 (2011) 343-346.

[40] H. Möller, E.P. Masuku, The influence of liquid surface segregation on the pitting corrosion behavior of semi-solid metal high pressure die cast alloy F357, Open Corrosion Journal 2 (2009) 216-220.

[41] E.P. Masuku, H. Möller, U.A. Curle, P.C. Pistorius, W. Li, Influence of surface liquid segregation on corrosion behavior of semi-solid metal high pressure die cast aluminium alloys, Transactions of Nonferrous Metals Society of China 20 (2010) s837-s841. 
[42] S.U. Mariani, A Da Forno, M. Bestetti, Corrosion behaviour of high pressure die-cast and semi-solid cast AZ91, AM60 and AM50 alloys, Solid State Phenomena (2012) Accepted for publication.

[43] R. Akhter, L. Ivanchev, C.V. Rooyen, P. Kazadi, H.P. Burger, Laser welding of SSM cast A356 aluminium alloy processed with CSIR-rheo technology, Solid State Phenomena 116117 (2006) 173-176.

[44] M. Theron, H.P. Burger, C. Van Rooyen, L.H. Ivanchev, Laser welding of A357 aluminium alloy(2008) ICALEO 2008 - Proceedings of the 27th International Congress on Applications of Lasers and Electro-Optics (2008) 34-40.

[45] G. Govender, L. Ivanchev, H. Burger, R. Knutsen, G. Kunene, Weldability of SSM rheo processed aluminum alloy A356, Solid State Phenomena 141-143 (2008) 773-778.

[46] R. Akhter, L. Ivanchev, H.P. Burger, Effect of pre/post T6 heat treatment on the mechanical properties of laser welded SSM cast A356 aluminium alloy, (2007) Materials Science and Engineering A447 (2007) 192-196.

[47] M. Theron, R.D. Knutsen, L.H. Ivanchev, H.P. Burger, Effect of heat treatment on the properties of laser-beam welded rheo-cast F357 aluminum, Journal of Materials Processing Technology 212 (2012) 465-470.

[48] G. Kunene, G. Govender, L. Ivanchev, R. Knutsen, H. Burger, The influence of heat treatments for laser welded semi solid metal cast A356 alloy on the fracture mode of tensile specimens, Solid State Phenomena 141-143 (2008) 169-174.

[49] M. Theron, H. Burger, L. Ivanchev, C. van Rooyen, Property and quality optimization of laser welded rheo-cast F357 aluminum alloy, Solid State Phenomena (2012) Accepted for publication.

[50] M. du Toit, P. Letsoalo, H. Möller, Fusion welding of rheocast semi-solid metal (SSM) processed aluminium alloy 7017, Solid State Phenomena (2012) Accepted for publication. 